\title{
PENAMBAHAN PREBIOTIK BERBEDA PADA PAKAN UNTUK MENINGKATKAN PERTUMBUHAN UDANG VANAME (Litopenaeus vannamei)
}

\section{THE ADDITION OF DIFFERENT PREBIOTICS ON FEED TO INCREASE THE GROWTH OF WHITE SHRIMP (Litopenaeus vannamei)}

\author{
Sri Ramdhani ${ }^{1 *}$, Dewi Nur'aeni Setyowati ${ }^{1)}$, Baiq Hilda Astriana ${ }^{1)}$ \\ ${ }^{1)}$ Program Studi Budidaya Perairan, Universitas Mataram \\ J1. Pendidikan No, 37 Mataram, NTB
}

\begin{abstract}
Abstrak
Udang vaname merupakan salah satu jenis udang yang banyak dibudidayakan di Indonesia. Udang ini banyak digemari dan memiliki nilai ekonomis yang cukup tinggi, bahkan menjadi primadona dari Indonesia. Akan tetapi, kegiatan budidaya udang menghadapi permasalahan terkait faktor lingkungan, penyakit, pertumbuhan yang lambat, serta kematian massal. Hal ini berakibat menurunkan tingkat produktivitas udang vaname. Salah satu pendekatan alternatif yang dapat dilakukan untuk mengatasi permasalahan tersebut yaitu dengan penambahan prebiotik pada pakan. Tujuan dari penelitian ini adalah untuk mengetahui pengaruh penambahan prebiotik yang berbeda pada pakan terhadap pertumbuhan udang vaname (Litopanaeus vannamei). Penelitian ini menggunakan metode Rancangan Acak Lengkap (RAL) yaitu dengan 4 perlakuan dan 3 ulangan, perlakuannya adalah Kontrol K ( pakan tanpa prebiotik), P1 (pakan pellet dengan penambahan prebiotik ubi 2\%), P2 (pakan pellet dengan penambahan prebiotik kentang $2 \%$ ), P3 ( pakan pellet dengan penambahan prebiotik ubi $1 \%$ dan kentang 1\%). Data yang diperoleh dianalisa menggunakan analysis of variance (ANOVA) dengan tingkat signifikan 5\%. Hasilnya menunjukkan bahwa tidak ada perbedaan yang signifikan antara perlakuannya untuk tingkat laju pertumbuhan spesifik, bobot mutlak, rasio konversi pakan, dan pertumbuhan mutlak.
\end{abstract}

Kata kunci : udang vaname, prebiotik, pertumbuhan

\begin{abstract}
Vaname shrimp is one type of shrimp that is widely cultivated in Indonesia. These shrimp are very popular and have high economic value, and even become favorite commodity from Indonesia. However, shrimp farming activities dealing with problems related to environmental factors, disease, slow growth, and mass death. This resulted in lowering the level of productivity of vaname shrimp. One alternative approach that can be done to overcome these problems is by adding prebiotics in feed. The purpose of this study was to determine the effect of different prebiotics addition on feed on the growth of vaname shrimp (Litopanaeus vannamei). This study uses a completely randomized design (CRD) method, with 4 treatments and 3 replications, the treatments include Control $\mathrm{K}$ (feed without prebiotics), P1 (pellet feeding with the addition of $2 \%$ sweet potato prebiotics), P2 (feed pellets with the addition of $2 \%$ prebiotic potatoes), $\mathrm{P} 3$ (feed pellet with the addition of $1 \%$ sweet potato prebiotics and $1 \%$ potatoes). The data obtained were analyzed using analysis of variance (ANOVA) to with significant level of 5\%. The result shows that there are no significant differences among the treatments for specific growth rates, absolute weights, feed conversion ratios, absolute growth.
\end{abstract}

Keywords : vaname shrimp, prebiotics, growth

\section{Pendahuluan}

Udang vaname merupakan salah satu jenis udang yang banyak dibudidaya di Indonesia. Udang ini banyak digemari dan memiliki nilai ekonomis yang cukup tinggi,

"korespondensi : nanyramdhani94@yahoo.com bahkan menjadi primadona dari Indonesia. Permintaan udang yang terus meningkat mendorong petani untuk membudidayakan udang secara intensif.

Akan tetapi, kegiatan budidaya udang menghadapi permasalahan terkait faktor 
lingkungan, penyakit, pertumbuhan yang lambat, serta kematian massal. Hal ini berakibat menurunkan tingkat produktivitas udang vaname. Salah satu pendekatan alternatif yang dapat dilakukan untuk mengatasi permasalahan tersebut yaitu dengan penambahan prebiotik pada pakan.

Prebiotik merupakan karbohidrat yang diklasifikasikan menurut ukuran molekul atau derajat polimerisasi dan terdiri dari monosakarida, oligosakarida, dan polisakarida. Prebiotik yang diberikan akan berperan dalam meningkatkan pertumbuhan, tingkat kelangsungan hidup, efisiensi pakan, serta komposisi bakteri yang menguntungkan dalam saluran pencernaan ikan (Merrifield dkk., 2010 dalam Azhar, 2013).

Tujuan dari penelitian ini adalah untuk mengetahui pengaruh penambahan prebiotik berbeda pada pakan terhadap pertumbuhan udang vaname (Litopenaeus vannamei). Penelitian ini diharapkan dapat memberikan informasi kepada masyarakat dan pembudidaya mengenai bagaimana pengaruh penambahan prebiotik berbeda pada pakan terhadap pertumbuhan udang vaname, sehingga dapat meningkatkan hasil produksi pada budidaya udang vaname.

\section{Metode Penelitian}

Penelitian ini dilaksanakan pada 23 April sampai 24 Mei 2018 yang bertempat di Balai Pengembangan Budidaya Perikanan Pantai (BPBPP) Sekotong, Kabupaten Lombok Barat. Alat yang digunakan dalam penelitian adalah set aerasi , kontainer, selang sifon , plastik hitam, baskom kecil, toples , wadah pakan, timbangan digital, shelter, thermometer, $\mathrm{pH}$ meter, DO meter, refraktometer, alat tulis , kamera, scope net, evaporator vacum, ember kecil , pisau, nampan, blender, kertas saring, micropipet, gelas ukur, Amonia meter, kompor gas, hot plate stirrer. Bahan yang digunakan yaitu udang vaname berumur 20 hari, pakan pellet komersil, air laut, larutan klorin, larutan na-thiosulfat, etanol, prebiotik (ubi dan kentang), dan kertas label. Metode penelitian yang digunakan adalah metode eksperimental menggunakan Rancangan Acak Lengkap (RAL) yaitu dengan 4 perlakuan dan 3 ulangan; Perlakuan Kontrol K (Pakan pellet tanpa prebiotik), P1 (Pakan pellet dengan penambahan prebiotik ubi 2\%), P2 (Pakan pellet dengan penambahan prebiotik kentang
2\%), P3 (Pakan pellet dengan penambahan prebiotik ubi $1 \%$ dan kentang $1 \%$ ).

\section{Prosedur penelitian \\ Persiapan prebiotik ubi dan kentang}

Ubi jalar dan kentang sebanyak $4 \mathrm{~kg}$ dibersihkan terlebih dahulu dan dilakukan pengupasan menggunakan pisau dan diiris. Irisan ubi jalar dan kentang dikeringkan di dalam oven pada suhu $55^{\circ} \mathrm{C}$ selama 18 jam hingga irisan ubi dan kentang dapat mudah dihancurkan dengan tangan. Irisan ubi dan kentang digiling dengan blender dan ditimbang tepung ubi jalar dan kentang sebanyak 50 gram dan selanjutnya dilakukan pengukusan, hasil pengukusan sebanyak 50 gram disuspensikan ke dalam etanol $70 \%$ sebanyak $500 \mathrm{ml}$. Dilakukan pengadukkan diatas hot plate stirrer yang menggunakan magnetic stirrer selama 15 jam dengan kecepatan pengadukan $3 \mathrm{~m} / \mathrm{s}$. Setelah itu penyaringan menggunakan kertas saring whatman no 1 (Azhar, 2014). Proses ini dilakukan di Laboratorium Program Studi Budidaya Perairan, filtrat yang diperoleh dipekatkan menggunakan evaporator vakum pada suhu $70^{\circ} \mathrm{C}$ yang sesuai dengan metode Widanarni dkk. ( 2014). Pemekatan dilakukan di Laboratorium Kimia Analitik. Hasil pemekatan disimpan di kulkas dengan suhu $3^{\circ} \mathrm{C}$.

\section{Persiapan Pakan yang Diberikan Prebiotik}

Pakan yang digunakan dalam pemeliharaan adalah pakan pellet komersil dengan kandungan protein $40 \%$. Pakan yang telah disediakan diberikan prebiotik sesuai dengan dosis pada setiap perlakuannya, prebiotik diteteskan dengan menggunakan mikro pipet pada pakan.

\section{Persiapan Wadah Pemeliharaan}

Wadah pemeliharaan yang digunakan adalah bak kontainer sebanyak 12 buah dengan ukuran kontainer $40 \times 30 \times 12,5 \mathrm{~cm}$. Kontainer diisi dengan air laut sebanyak 15 liter.

Setiap kontainer dilakukan pemasangan plastik hitam di sekeliling bak, dengan tujuan untuk mengurangi tingkat stress pada udang saat pemeliharaan berlangsung. Selanjutnya shelter (berupa pipa paralon dengan ukuran 7 $\mathrm{cm}$ dengan diamter pipa yaitu $1 / 2$ inch) diletakkan secara acak di bagian dasar kontainer sebagai tempat persembunyian 
udang. Aerasi satu unit pada masing- masing kontainer untuk menyuplai oksigen selama pemeliharaan udang. Kemudian diberikan penutup pada bagian atas bak, agar udang tidak melompat. Bak kontainer diletakkan sesuai rancangan percobaan.

\section{Persiapan Media Air}

Air laut yang digunakan ditreatment terlebih dahulu, menggunakan klorin dengan dosis 30 ppm didiamkan selama 24 jam Kemudian air yang ditreatment dinetralisir dengan Na-thiosulfat dengan dosis 15 ppm. Klorin tersebut berfungsi untuk menghilangkan patogen yang terdapat di dalam air laut yang tertampung di bak penampungan. Sedangkan tiosulfat berfungsi untuk menetralisir penggunaan klorin (Widanarni dkk., 2014).

\section{Persiapan Hewan Uji}

Udang vaname yang digunakan adalah PL 20, berasal dari Balai Produksi Induk Udang Unggul dan Kekerangan (BPIU2K) Kecamatan Karangasem, Kabupaten Krangasem, Bali. Sebelum digunakan, udang diadaptasi terlebih dahulu selama 1 hari di dalam bak kontainer, udang diseleksi dengan cara melihat ukuran tubuh dan berenang akif. kemudian udang dilakukan penebaran sebanyak 15 ekor/kontainer.

\section{Pelaksanaan Penelitian \\ Penimbangan Bobot Awal Udang Vaname}

Alat yang digunakan untuk mengukur berat udang vaname yaitu timbangan analitik. Penimbangan udang vaname dilakukan untuk mengetahui berat awal udang. Penimbangan dilakukan dengan mengambil sampel udang vaname sebanyak 10 ekor pada setiap kontainer sesuai dengan perlakuan.

\section{Penebaran}

Penebaran udang vaname dilakukan pada pagi hari sebanyak 15 ekor pada bak penampung dengan menggunakan serokan, lalu ditebar pada masing-masing kontainer dengan bobot awal udang 0,002 g.

\section{Pemberian Pakan}

Pemberian pakan pellet komersil dengan kandungan protein $40 \%$ dan prebiotik sesuai dosis pada setiap perlakuan, frekuensi pemberian pakan 3 kali sehari pada pukul 08.00, 13.00, 18.00 WITA dengan kebutuhan pakan sebesar $15 \%$ dari total biomassa per kontainer. Sisa pakan pada dasar kontainer diambil, kemudian dikeringkan atau dioven dan ditimbang untuk menghitung FCR (Feed Convertion Ratio).

\section{Pengelolaan Kualitas Air}

Pengukuran kualitas air dilakukan menggunakan alat ukur $\mathrm{pH}$ meter, Refraktormeter, Thermometer, Amonia meter, DO meter selama 7 hari sekali setelah dilakukan pergantian air.

\section{Penimbangan Bobot Akhir Udang Vaname}

Penimbangan bobot udang vaname dilakukan pada akhir pemeliharaan yaitu 30 hari, yang bertujuan untuk mengetahui bobot akhir udang yang telah diberikan perlakuan. Penimbangan menggunakan timbangan analitik. Penimbangan dilakukan dengan cara mengambil sampel udang vaname sebanyak 10 ekor dari masing-masing unit percobaan.

\section{Analisis data}

Parameter yang diuji secara statistik adalah sintasan atau kelangsungan hidup udang vaname, $\mathrm{S}=(\mathrm{Nt} / \mathrm{No}) \times 100 \%$; diketahui $\mathrm{Nt}$ : jumlah udang vaname pada akhir perlakuan (ekor) dibagi dengan No : jumlah udang vaname awal (ekor); laju pertumbuhan harian $=S G R=\frac{\ln W t-\ln W o}{t} \times 100 \%$, SGR $=$ lajur pertumbuhan harian (\%/hari); $\mathrm{Wt}=$ bobot rata-rata udang di akhir pemeliharaan (g); Wo = bobot rata-rata udang di awal pemeliharan (g) ; t= lama waktu pemeliharaan (hari); Pertumbuhan bobot mutlak adalah $\mathrm{Wm}=\mathrm{Wt}-$ $\mathrm{Wo} ; \mathrm{Wm}=$ pertumbuhan bobot mutlak $(\mathrm{g})$; $\mathrm{Wt}=$ bobot rata-rata udang pada akhir pemeliharaan $(\mathrm{g})$; Wo = bobot rata-rata udang pada awal pemeliharaan $(\mathrm{g})$; rasio konversi pakan FCR = $\frac{\sum F \text { pakan yang diberikan }-\sum F \text { sisa pakan }}{(B t+B m)-B o} ; \mathrm{FCR}=$ Rasio konversi pakan $(\mathrm{g}) ; \sum \mathrm{F}=$ jumlah pakan (g); $\mathrm{Bt}=$ biomassa udang pada akhir penelitian (g); $\mathrm{Bm}=$ biomassa udang yang mati $(\mathrm{g}) ; \mathrm{Bo}=$ biomassa udang pada awal penelitian $(\mathrm{g})$. Data yang diperoleh diuji secara statistik, dimana analisa data menggunakan Anova (Analysis of Variance), dan jika hasil menunjukkan signifikan, sebaiknya dilakukan uji lanjut menggunakan Tuckey HSD.. 
Tabel 1. Analisis data SGR, bobot mutlak dan rasio konversi pakan

\begin{tabular}{lcccc}
\hline \multirow{2}{*}{\multicolumn{1}{c}{ Parameter }} & \multicolumn{4}{c}{ Perlakuan } \\
\cline { 2 - 5 } & $\mathrm{K}$ & $\mathrm{P} 1$ & $\mathrm{P} 2$ & $\mathrm{P} 3$ \\
\hline SGR $(\% / \text { hari })^{\mathrm{ns}}$ & $0,114 \pm 1,071$ & $0,114 \pm 0,647$ & $0,123 \pm 0,56$ & $0,120 \pm 0,636$ \\
Bobot mutlak $(\mathrm{g})^{\mathrm{ns}}$ & $0,053 \pm 0,008$ & $0,062 \pm 0,011$ & $0,073 \pm 0,024$ & $0,073 \pm 0,013$ \\
FCR & $0,209 \pm 0,470$ & $0,202 \pm 0,546$ & $0,185 \pm 0,619$ & $0,152 \pm 0,935$ \\
\hline
\end{tabular}

Tabel 2. Hasil pengukuran kualiatas air

\begin{tabular}{|c|c|c|c|c|c|}
\hline \multirow{2}{*}{ Parameter } & \multicolumn{4}{|c|}{ Perlakuan } & \multirow{2}{*}{ Referensi } \\
\hline & $\mathrm{K}$ & P1 & $\mathrm{P} 2$ & P3 & \\
\hline Suhu $\left({ }^{\circ} \mathrm{C}\right)$ & $26-29$ & $26-29$ & $26-29$ & $26-29$ & 26-30 (Dede dkk., 2014) \\
\hline $\mathrm{pH}$ & $7,8-7,9$ & $7,8-7,9$ & $7,8-7,9$ & $7,8-7,9$ & 7-8,5 (Dede et al, 2014) \\
\hline $\mathrm{DO}(\mathrm{mg} / \mathrm{l})$ & $6,0-6,3$ & $6,0-6,3$ & $6,2-6,3$ & $6,2-6,3$ & 4-8 (Fuady dkk., 2013) \\
\hline Salinitas (ppt) & $33-35$ & $33-35$ & $33-35$ & $33-35$ & $\begin{array}{l}\text { 33-40 (Mustafa et al, } \\
\text { 2007) }\end{array}$ \\
\hline Amoniak (mg/l) & $0,01-0,04$ & $0,01-0,04$ & $0,01-0,04$ & $0,01-0,04$ & $\begin{array}{l}0,01-0,05 \\
\text { (KEP.28/MEN/2004) }\end{array}$ \\
\hline
\end{tabular}

\section{Hasil}

\section{Laju Pertumbuhan Spesifik (SGR) dan Bobot Mutlak}

Berdasarkan Tabel 1. dapat dilihat bahwa pemberian perlakuan prebiotik berbeda antar perlakuan memberikan hasil yang tidak berbeda nyata $(\mathrm{P}>0,05)$ non signifikan antar perlakuannya yaitu perlakuan Kontrol, P1, P2 dan P3 terhadap laju pertumbuhan spesifik dan bobot mutlak. Dalam pemberian prebiotik pada udang belum ada referensi yang menyebutkan bahwa penambahan prebiotik berperan terhadap pertumbuhan udang.

\section{Rasio Konversi Pakan (FCR)}

Berdasarkan Tabel 1. pemberian perlakuan prebiotik berbeda dengan bahan ubi dan kentang, memberikan hasil yang tidak berbeda nyata $(\mathrm{P}>0,05)$ non signifikan antar perlakuannya yaitu perlakuan Kontrol , P1, P2 dan P3. Nilai rasio konversi pakan yang rendah pada setiap perlakuan dan kontrol.

\section{Kelangsungan Hidup}

Berdasarkan Gambar 1. Selama pemeliharaan, pemberian prebiotik berbeda antar ubi dan kentang pada pakan, pelakuan Kontrol, P1, P2 dan P3, dengan tingkat kelangsungan hidup udang vaname diakhir pemeliharaan yaitu sebesar $100 \%$.

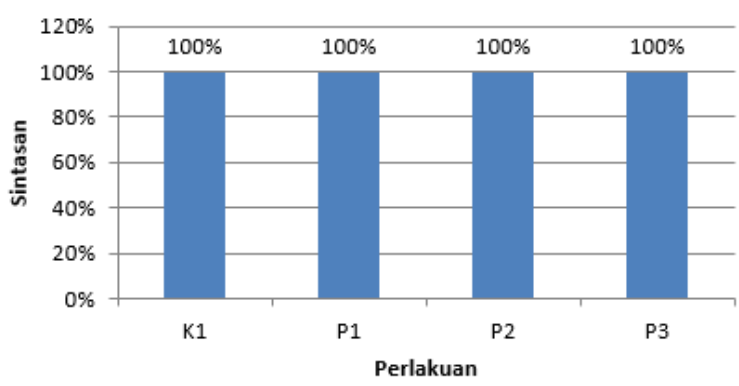

Gambar 1. Tingkat kelangsungan hidup udang vaname (Litopenaeus vannamei).

\section{Kualitas Air}

Pengukuran kualitas air selama pemeliharaan 30 hari, dilakukan pengkuran selama satu minggu sekali dengan parameter yang diukur yaitu meliputi Suhu, $\mathrm{pH}$, salinitas, DO, dan amonia. Hasil pengamatan yang didapatkan selama pemeliharaan dapat dilihat pada Tabel 2.

\section{Pembahasan}

\section{Laju Pertumbuhan Spesifik (SGR) dan Bobot Mutlak}

Pemberian prebiotik pada udang belum ada referensi yang menyebutkan bahwa penambahan prebiotik berperan terhadap pertumbuhan udang, tetapi pemberian perlakuan prebiotik pada ikan telah berhasil dilakukan oleh Djauhari, dkk. (2017) dimana dengan penambahan prebiotik sebesar $2 \%$ 
pada pakan memberikan hasil yang signifikan, perlakuan prebiotik ternyata mampu memberikan pengaruh yang nyata dibandingkan dengan perlakuan kontrol terhadap pertumbuhan, populasi bakteri pada usus ikan mas, mampu meningkatkan aktivitas enzim pada saluran pencernaan.

Kandungan oligosakarida pada prebiotik mampu meningkatkan efek terhadap penyerapan pada usus yang memiliki dampak positif pada pertumbuhan. Selain itu penelitian oleh Sudiarto, dkk. (2014), menyebutkan bahwa penambahan prebiotik pada pakan meningkatkan pertumbuhan ikan nila, dengan dosis prebiotik sebesar $1 \%$ dan $2 \%$ mampu memberikan pengaruh yang signifikan terhadap pertumbuhan ikan nila. Hal ini terkait dengan kemampuan ikan untuk mencerna pakan yang diberikan kemudian menyimpannya dalam tubuh, sehingga menghasilkan juga tingkat pemanfaatan pakan yang lebih efisien dibandingkan dengan kontrol. Tidak hanya meningkatkan pertumbuhan, prebiotik yang diberikan juga mampu memberikan peningkatan jumlah bakteri pada saluran pencernaan, dengan adanya penambahan prebiotik pada pakan diduga telah menstimulir pertumbuhan mikroflora normal di dalam saluran pencernaan ikan nila, sehingga jumlah populasi bakteri pada perlakuan prebiotik lebih tinggi dibandingkan dengan kontrol.

Pada ikan, tidak hanya perlakuan penambahan prebiotik saja, tetapi perlakuan sinbiotik juga digunakan untuk pencegahan vibriosis pada ikan kerapu bebek. Dari hasil penelitian Saputra, dkk. (2013), pemberian pakan dengan sinbiotik yaitu prebiotik $2 \%$ ditambahkan dengan probiotik $1 \%$ dan dinfeksi $V$. alginolyticus, memberikan hasil laju pertumbuhan harian yang lebih tinggi $(13,29 \pm 0,98)$ dibandingkan dengan kontrol $(9.62 \pm 0,98)$. Hal ini membuktikan bahwa penggunaan sinbiotik dapat memacu performa pertumbuhan ikan kerapu bebek, pemberian probiotik NP5 diduga telah meningkatkan aktivitas enzim eksogen. Peningkatan pertumbuhan bakteri NP5 pada perlakuan sinbiotik diduga juga disebabkan dari prebiotik yang diberikan, dimana prebiotik yang diekstrak dari ubi jalar secara efektif dapat mendukung pertumbuhan bakteri probiotik.

Selain itu pemberian prebiotik melalui pakan juga dapat meningkatkan panjang mikrovil usus. Panjang mikrovil usus dapat membantu meningkatkan penyerapan nutrien sehingga dapat meperbaiki performa pertumbuhan pada inang. Hasil penelitian lainnya yaitu perlakuan pakan uji dengan pemberian probiotik dan prebiotik terhadap juvenil ikan kerapu bebek (Comileptes altivelis) dengan penambahan prebiotik $2 \%$ dan probiotik $1 \%$ serta diinfeksi Vibrio alginolyticus. Hasil yang diperoleh pada penggunaan probiotik, prebiotik dan sinbiotik terbukti menunjukkan hasil pertumbuhan harian yang signifikan dibandingkan dengan kontrol, yaitu menunjukkan nilai $13,79 \%$ dibandingkan dengan kontrol yang hanya menunjukkan laju pertumbuhan harian sebesar 8,79 pada kontrol negatif dan 9,62 pada kontrol positif (Azhar., 2013).

Untuk udang, prebiotik tidak memberikan pengaruh yang signifikan terhadap pertumbuhan, tetapi berperan lebih untuk ketahanan terhadap penyakit. Penambahan prebiotik pada pakan tidak cukup, perlu penambahan probiotik, dengan perlakuan sinbiotik, sehingga dapat meningkatkan laju pertumbuhan spesifik dan bobot mutlak pada pemeliharaan udang vaname. Beberapa penelitian yang telah dilakukan yaitu penelitian Harpeni dkk. (2017), yang menggunakan prebiotik ubi $4 \%$ dengan probiotik $6 \%$ Bacillus sp. D2.2 dengan hasil yang signifikan mampu meningkatkan pertumbuhan udang vaname, dengan meningkatkan aktivitas enzim pada pencernaan udang, mampu menyerap banyak nutrisi serta memberikan hasil yang signifikan dengan metode sinbiotik yang terbaik, mampu melindungi udang dari infeksi bakteri Vibrio harveyi dengan meningkatkan imunitas.

Penelitian selanjutnya dengan penambahan prebiotik dalam aplikasi sinbiotik, yang menggabungkan prebiotik $2 \%$ dan probiotik $1 \%$ dalam pencegahan infeksi Infectious myonecrosis virus pada udang vaname dengan uji tantang dengan IMNV melalui pemberian pakan dengan cacahan udang yang positif terinfeksi IMNV. Dari hasil yang didapatkan diketahui bahwa pemberian sinbiotik memberikan performa pertumbuhan udang yang lebih tinggi dibandingkan dengan kontrol yang tidak diberikan prebiotik dan probiotik. Tingginya performa pertumbuhan pada perlakuan sinbiotik diduga disebabkan kemampuan probiotik Vibrio SKT-b yang diberikan mampu meningkatkan aktivitas enzim pencernaan sehingga pemanfaatan 
pakan dan proses pencernaan dapat lebih selektif. Diduga bakteri prebiotik mampu bertahan dalam waktu beberapa minggu, selain itu diduga prebiotik yang diberikan juga berkontribusi dalam mempertahankan populasi bakteri yang mendukung performa pertumbuhan udang, sehingga aplikasi penggabunggan prebiotik dan probiotik sangat cocok untuk dilakukan pada udang (Widanarni dkk., 2014).

\section{Rasio Konversi Pakan (FCR)}

Nilai rasio konversi pakan pada penelitian ini rendah pada setiap perlakuan dan kontrol. Nilai konversi pakan berbanding terbalik dengan pertambahan bobot, sehingga semakin rendah nilainya maka semakin efesien udang dalam memanfaatkan pakan yang dikosumsinya untuk pertumbuhan (Riani dkk., 2012). Nilai rasio konversi pakan yang semakin kecil atau rendah menunjukkan mutu pakan yang semakin baik yang mana tingkat kecernaan pakan tersebut semakin tinggi. Kecilnya rasio konversi pakan dipengaruhi oleh beberapa faktor yaitu kualitas pakan untuk pertumbuhan, ukuran dan kualitas air ( Zainuddin dkk., 2014).

Nilai konversi pakan yang rendah menunjukkan bahwa pakan yang diberikan hampir sepenuhnya dimanfaatkan. Sehingga, semakin rendah nilai konversi pakan maka, pakan yang diberikan semakin efisien digunakan untuk pertumbuhan dan sebaliknya. Jika semakin tinggi nilai konversi pakan, maka pakan yang diberikan semakin tidak efisien digunakan untuk pertumbuhan ( Saltin dkk., 2016).

\section{Kelangsungan Hidup}

Kelangsungan hidup merupakan suatu perbandingan antara jumlah hewan akuatik yang hidup pada akhir pemeliharaan dengan jumlah hewan akuatik yang hidup pada awal pemeliharaan. Dalam kelangsungan hidup udang yang dapat diperhatikan yaitu pengelolaan dalam pemberian pakan dan pengelolaan kualitas air yang baik pada media pemeliharaan Riani dkk. (2012). Hal ini sesuai dengan pernyataan Purnamasari dkk. (2017) yang menyatakan bahwa faktor yang paling mempengaruhi kelangsungan hidup udang yaitu pengelolaan dalam pemberian pakan dan pengelolaan kualitas air yang baik pada media pemeliharaan.
Tingkat kelangsungan hidup udang vaname tinggi selama pemeliharaan, diduga dikarenakan luasan wadah yang digunakan sesuai untuk ukuran udang yang kecil dan padat penebaran yang tidak terlalu tinggi (Amal, 2012). Menurut (Purnamasari et al., 2017), menyatakan bahwa tingginya tingkat kelangsungan hidup pada udang vaname disebabkan oleh kepadatan yang rendah, sehingga pakan dimanfaatkan dengan baik, serta pengelolaan kualitas air yang cukup baik, sehingga udang dapat bertahan hidup.

\section{Kualitas Air}

Dari hasil pengukuran kualitas air selama pemeliharaan masih dalam taraf normal dan berada pada kisaran yang baik untuk budidaya udang vaname. Suhu pada perlakuan kontrol, P1, P2 dan P3 yaitu $26-29{ }^{\circ} \mathrm{C}$. Hal ini sesuai dengan pernyataan Dede dkk. (2014) yang menyatakan bahwa suhu perairan yang baik untuk pemeliharaan udang berkisar 26 hingga $30^{\circ} \mathrm{C}$, karena pada kisaran suhu tersebut udang dapat melakukan proses pencernaan makanan dengan baik sehingga diikuti pertumbuhan udang yang baik pula serta suhu air sangat berpengaruh terhadap proses kimia dan biologi perairan, daya kelarutan oksigen di dalam air akan semakin rendah jika suhu air semakin meningkat dan sebaliknya tingkat konsumsi oksigen akan semakin tinggi. Hal ini dapat menyebabkan tingkat oksigen terlarut berkurang sehingga dapat mempengaruhi kehidupan udang.

Nilai $\mathrm{pH}$ yang diperoleh selama pemeliharaan pada perlakuan Kontrol, P1, P2, dan P3 yaitu berkisar 7,8-7,9 . Kondisi ini masih dapat dikatakan normal. Hal ini sesuai dengan pernyataan Dede dkk. (2014) yang menyatakan bahwa $\mathrm{pH}$ (derajat keasaman) untuk dapat hidup dengan baik pada pemeliharaan udang berkisar 7-8,5 (Dede dkk., 2014). Dimana $\mathrm{pH}$ air mempengaruhi tingkat kesuburan perairan karena mempengaruhi kehidupan jasad renik. Perairan asam $(\mathrm{pH}$ kurang dari 7) akan kurang produktif dan dapat membunuh udang dalam air. Kondisi ini akan menyebabkan oksigen terlarut berkurang dan sebagai akibatnya konsumsi oksigen menurun.

Nilai DO selama pemeliharaan pada perlakuan Kontrol, P1, berkisar antara 6,0-6,3 dan P2, P3 berkisar antara 6,2-6,3 mg/L, kondisi ini masih dikatakan normal, sehingga tidak adanya kompetisi dalam penggunaan 
oksigen terlarut dan tingkat kepadatan udang yang tidak terlalu tinggi. Kebutuhan oksigen di dalam air akan tercukupi. Hal ini sesuai dengan pernyataan Dede dkk. (2014) yang menyatakan oksigen terlarut dalam pemeliharan udang vaname berkisar antara 4-8 mg/L, jika kebutuhan oksigen tidak tercukupi akan menyebabkan udang akan stress dan mengakibatkan tingkat kelangsungan hidup udang akan menurun.

Hasil pengukuran salinitas selama pemeliharaan pada setiap perlakuan yaitu perlakuan kontrol, P1, P2, P3 berkisar berkisar antara 33-35 ppt, kondisi ini masih dikatakan normal. Hal ini sesuai dengan pernyataan Mustafa dkk. (2007), yang menyatakan bahwa pertumbuhan dan sintasan terbaik udang vaname dijumpai pada salinitas 33-40 ppt. Salinitas dapat berperan dalam berlangsungnya proses osmoregulasi dan juga membantu proses ketika udang siap untuk moulting.

Hasil pengukuran amonia didapatkan hasil pada setiap perlakuan Kontrol, P1, P2, P3 yaitu berkisar antara $0,01-0,04 \mathrm{mg} / \mathrm{L}$. Hal ini bersdasarkan dengan KEP.28/MEN (2004), yang manyatakan bahwa kisaran amonia dalam pemeliharaan udang vaname $0,01-0,05$ $\mathrm{mg} / \mathrm{L}$. Dimana kisaran konsentrasi tersebut udang masih dapat mengikat oksigen dengan baik sehingga tidak menyebabkan nafsu makan menurun (Dede dkk., 2014).

\section{Kesimpulan}

Pemberian prebiotik berbeda pada pakan memberikan hasil yang tidak berbeda nyata (non signifikan) pada setiap perlakuan terhadap pertumbuhan udang vaname (Litopenaeus vannamei).

\section{Daftar Pustaka}

Azhar, F. (2014). Kajian Pemberian Probiotik, Prebiotik dan Sinbiotik untuk Pencegahan Penyakit Vibriosis Pada Ikan Kerapu Bebek (Cromileptes altivelis). Sekolah Pascasarjana, Institut Pertanian Bogor.

Azhar, F. (2013). Pengaruh Pemberian Probiotik dan Prebiotik terhadap Performan Juvenile Ikan Kerapu Bebek (Comileptes Altivelis). Buletin Veteriner Udayana, 6 (1). .

Amal. (2012). Tingkat Kelangsungan Hidup, Pertumbuhan, Produksi Dan Konversi
Makanan Juvenil Udang Windu (Penaeus Monodon Fab) Dan Udang Putih (Penaeus merguiensis De Man) Dalam Keramba Di Laut. Universitas Negeri Makasar.

Dede, H., Riris,A., \& Gusti, D. (2014). Evaluasi Tingkat Kesesuaian Kualitas Air Tambak Udang BerdasarkanProduktivitas Primer PT. Tirta Bumi Nirbaya Teluk Hurun Lampung Selatan(Studi Kasus). Maspari Journal. 6 (1), 32-38.

Djauhari, R., Widanarni,. Sukenda., Muhammad. A. S., Muhammad, Z. J. R. (2017). Growth Performance and Health Status of Common Ca (Cyprinus carpio) Supplementd with Prebiotic from Sweet Potato (Iphomoea batatas L.) Extract. Pakistan Journal of Nutrisi. 16 (1), 155163.

Fuady, M. F., Mustofa. N. S., Haeruddin. (2013). Pengaruh Pengelolaan Kualitas Air Terhadap Tingkat Kelulushidupan dan Laju Pertumbuhan Udang Vaname (Litopenaeus Vannamei) Di Pt. Indokor Bangun Desa, Yogyakarta. Journal of Maquares. 2 (4), 155-162.

Harpeni, E., Limin,S., Wardiyanto., Ari,W., Laksmita, Y. (2017). Effect of Dietary Probiotic Bacillus sp. D2.2 Anbd Prebiotic Sweet Potato Extract on Growth Performance and Resistance to Vibrio harveyi In Pacific White Shirmp, Litopenaeus vannamei. Aquaculture Indonesia. 18 (1), 55-61.

Keputusan Menteri Kelautan dan Perikanan No. 28, (2004). Tentang Pedoman Umum Budidaya Udang di Tambak. Jakarta.

Mustafa, A., Irmawati, S., Hasnawi., Jesmond, S. (2007) . Hubungan Antara Faktor Kondisi Lingkungan Dan Produktivitas Tambak Untuk Penajaman Kriteria Kelayakan Lahan: 1. Kualitas Air. Jurnal Ris. Akuakultur. 2 (3) , 289302.

Purnamasari, B. (2017). Kinerja Produksi Ikan Synodontis Synodontis eupterus Pada Teknologi Bioflok C/N 12 dengan Pada Tebar Berbeda. Skripsi. Fakultas Perikanan dan Ilmu Kelautan. Institut Pertanian Bogor.

Riani, H., Rita, R., Walim,L. (2012). Efek Pengurangan Pakan Terhadap Pertumbuhamn Udang Vanname (Litopenaeus vannamei) PL-21 Yang 
Diberi Bioflok. Jurnal Perikanan dan Kelautan. 3 (3), 207-211.

Saputra, A. D., Sukenda., Widanarni. (2013). Aplikasi Sinbiotik Dengan Dosis Probiotik Berbeda Untuk Pencegahan Vibriosis Pada Ikan Kerapu Bebek. Jurnal Akuakultur Indonesia.12 (2), 169177.

Sudiarto, A. J., Mustahal., Achmad, N. P. (2014).Aplikasi Prebiotik Pada Pakan Komersial untuk Meningkatkan Kinerja Pertumbuhan Ikan Nila (Oreochromis niloticus). Perikanan dan Kelautan. 4 (4), 229-234.

Saltin, A., Muhammad, I., Agus, K. (2016). Pengaruh Penambahan Minyak Ikan Salmon dalam Pakan terhadap
Pertumbuhan dan Sintasan Post Larva Udang Windu (Penaeus monodon). Media Akuatika. 1 (4), 234-242.

Widanarni., Jeanni, I. N., Sukenda. (2014). Prebiotik, Probiotik, dan Sinbiotik untuk Mengendalikan Koeinfeksi Vibrio harveyi dan IMNV pada Udang Vanname. Akuakultur Indonesia. 13 (1), 11-20.

Zainuddin, Haryati., Siti, A., Surianti.( 2014). Pengaruh Level Karbohidrat dan Frekuensi Pakan Terhadap Rasio Konversi Pakan dan Sintasan Juvenil Litopenaeus Vannamei. Jurnal Perikanan (J. Fish. Sci.). XVI (1), 29-34. 